\title{
Incidence of Argyrophil Cells in Normal and Dysplastic Conditions of Human Uterine Cervix
}

\author{
Sujatha D'Costa ${ }^{\mathrm{a}, \mathrm{e}}$, Raghuveer C'Vasudevarao ${ }^{\mathrm{b}}$, Adhikari Prabha ${ }^{\mathrm{c}}$, \\ Sampath Madhyasta ${ }^{\text {a }}$ Chitra Prakash Rao ${ }^{\mathrm{d}}$
}

\begin{abstract}
Background: Cervical intraepithelial neoplasia, also known as cervical dysplasia, is the potentially premalignant transformation and abnormal growth of squamous cells on the surface of the cervix. Argyrophil cells occur rarely in the normal human uterine cervix but are found in a variety of invasive tumours arising in the cervix.

Methods: In this study, with the Grimelius argyrophilic reaction 317 normal uterine cervices were stained, out of which 158 cases (49.84\%) were positive. And 27 dysplastic cases of uterine cervices were stained with Grimelius argyrophilic reaction, out of which 25 $(92.59 \%)$ showed the argyrophilic positivity. When Normal cervix was compared with Dysplastic cervix the probability value was < 0.001 which was significantly higher. The immunomarkers used in the present study were Chromogranin A and Synaptophysin.
\end{abstract}

Results: Argyrophil cells in ectocervical epithelium are rare. It is the first study which reveals the comparison of the presence of argyrophilic cells in normal and dysplastic human uterine cervix, using Grimelius argyrophilic reaction and Immunohistochemical staining using Chromogranin A and Synaptophysin as argyrophilic markers with larger sample size and higher positivity.

Conclusion: From the results of our study it is clear that argyrophilia is a significant marker in dysplasia.

Keywords: Argyrophil cells; Grimelius reaction; Markers; Neuro-

Manuscript accepted for publication October 4, 2012

${ }^{a}$ Department of Anatomy, Cbs, Kmc, Bejai, Mangalore, Manipal University, Karnataka, India

${ }^{\mathrm{b}}$ Director of Post Graduate Studies \& Research, Yenepoya University, Deralakatte, Mangalore 575018, Karnataka, India

${ }^{\mathrm{c}}$ Department of Medicine, KMC, Manipal Unive4rsity, Karnataka, India

${ }^{\mathrm{d} D e p a r t m e n t ~ o f ~ A n a t o m y, ~ A J ~ M e d i c a l ~ C o l l e g e, ~ M a n g a l o r e, ~ K a r n a t a k a, ~}$ India

${ }^{\text {e}}$ Corresponding author: Sujatha D'Costa, Department of Anatomy, Centre for Basic Sciences, Kasturba Medical College, Bejai, Mangalore,

Manipal University -575004 Karnataka, India.

Emails: sujatha.dcosta@manipal.edu

doi: http://dx.doi.org/10.4021/jcs116w endocrine cells; Dysplasia; Normal cervix; Synaptophysin; Chromogranin A

\section{Introduction}

The normal uterine cervix is lined by single layered columnar epithelium. The epithelium is squamous on the ectocervix and columnar in the endocervix. Its lower region is covered by non-keratinizing stratified squamous epithelium, which contains glycogen $[1,2]$. The recurrent inflammation of the cervix is known as Chronic Cervicitis, which is an extremely common condition in adult females. This affects preferentially the squamo-columnar junction and endocervix and it may be accompanied by hyperemia, edema, fibrosis and metaplastic changes in the epithelium. It may also play a role in the initiation or promotion of cervical neoplasia [3]. Cervical intraepithelial neoplasia (CIN), also known as cervical dysplasia, is the potentially premalignant transformation and abnormal growth (dysplasia) of squamous cells on the surface of the cervix [4]. Most cases of CIN remain stable, or are eliminated by the host's immune system without intervention. However a small percentage of cases progress to become cervical cancer, usually cervical squamous cell carcinoma, if left untreated [5].

Argyrophil cells are neuroendocrine cells and they need the assistance of an external reducing agent to reduce silver solution to metallic silver [6]. According to Sivridis et al [7] it is suggested that Mullerian epithelial stem cells possess a potentiality for differentiation into Amine Precursor Uptake and Decarboxylation (APUD) cells. Argyrophilic cells occur rarely in the normal cervix but are found in a variety of invasive tumours arising in the uterine cervix such as preinvasive glandular lesions of the cervix [8]. Argyrophilic cells in the normal uterine cervix were first documented by Fox, Kazzaz and Langley [9] and subsequently by others [10-12]. The transformation zone of the uterine cervix is of utmost importance because cervical cancer and its precursors typically begin within it $[2,13]$.

In the present study we have used both Grimelius argyrophilic reaction and immunohistochemical technique for 

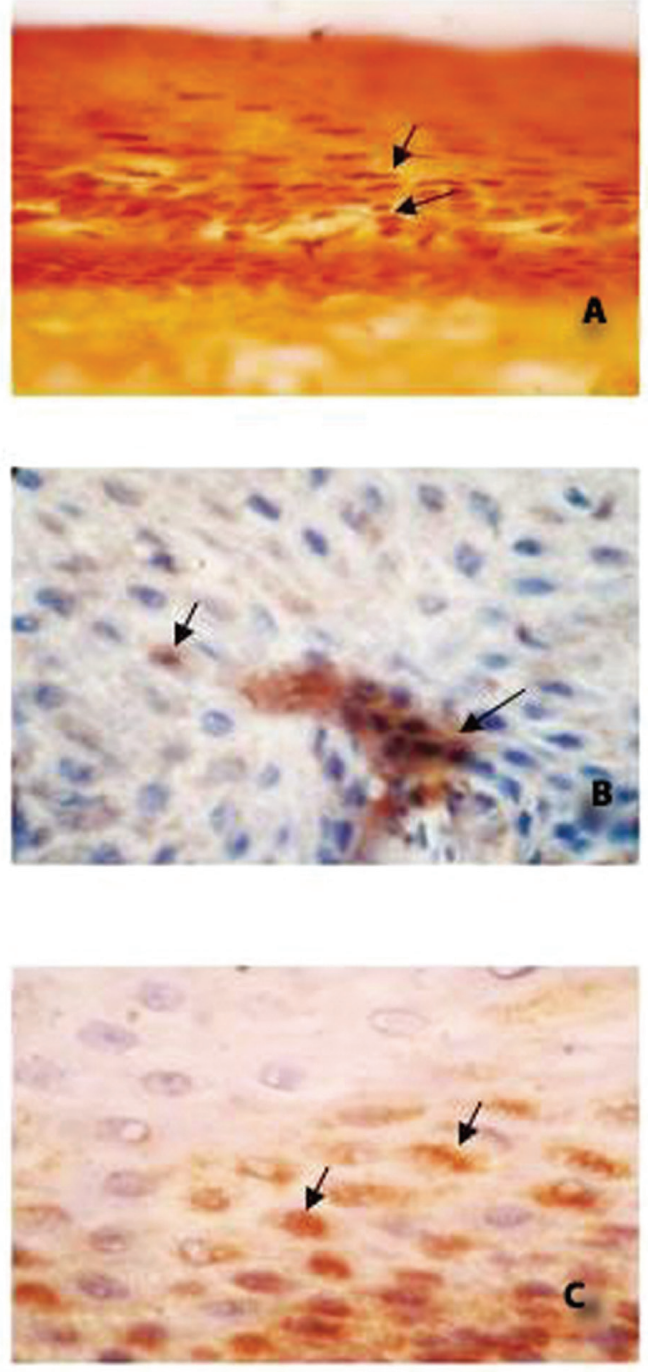

Figure 1. Normal Cervix. Photomicrograph A: Grimelius Argyrophil Reaction at $100 \times$ Arrows indicate the Argyrophil cells. Photomicrograph B: Immunoexpression with Chromogranin $\mathrm{A}$ at $100 \times$. Arrows indicate the $\mathrm{Cg} \mathrm{A}$ reaction. Location of reaction: Cytoplasmic. Intensity of reaction: Weak Photomicrograph C: Immunoexpression with Synaptophysin at $100 \times$, Arrows indicate the SYN reaction. Location of reaction: Cytoplasmic and Membranous. Intensity of reaction: Moderate.

qualitative analysis for the presence of argyrophil cells in normal human uterine cervix and compared with the dysplastic conditions of uterine cervices.

\section{Materials and Methods}

Random collection of 317 normal uterine cervices and 27 dysplastic uterine cervices from hysterectomy specimens which had their histopathological diagnosis confirmed in the Pathology department Kasturba Medical College, Man-
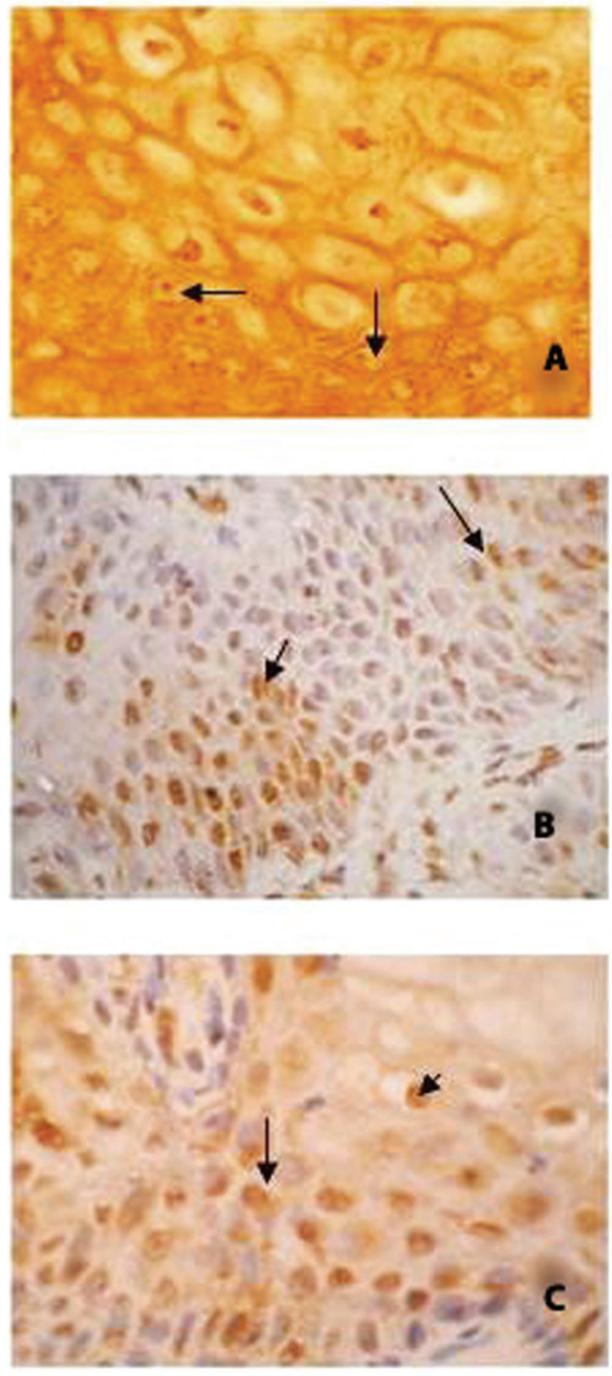

Figure 2. Dysplastic cervix. Photomicrograph A: Grimelius Argyrophil Reaction at $100 \times$, Arrows indicate the Argyrophil cells. Photomicrograph B: Immunoexpression with Chromogranin $\mathrm{A}$ at $100 \times$, Arrows indicate the $\mathrm{Cg} \mathrm{A}$ reaction. Location of reaction: Cytoplasmic and Nucleus. Intensity of reaction: Strong. Photomicrograph C: Immunoexpression with Synaptophysin at $100 \times$, Arrows indicate the SYN reaction. Location of reaction: Cytoplasmic and Nucleus. Intensity of reaction: Strong.

galore. The study was approved by the Ethical Committee. About 4 to $5 \mu$ thickness sections of each paraffin blocks stained with Grimelius Argyrophilic reaction as per standard procedure [14-19]. The Grimelius argyrophilic reaction is useful in detecting highly or moderately granulated neoplasms [14]. Tissue known to contain argyrophil granules such as spinal ganglion was used as a control for the Grimelius argyrophilic reaction. The Grimelius argyrophilic reaction is a well known procedure was used by employing the principle of impregnation with silver nitrate $\left(\mathrm{AgNO}_{3}\right)$ and reduction with hydroquinone and sodium sulphate. The sec- 
Table 1. Comparison of Percentage of Argyrophilic Cell Positive Cases in Normal With Dysplastic Conditions of Human Uterine Cervix

\begin{tabular}{llll}
\hline Groups & No. of Cases studied & No. of +ve Cases & $\begin{array}{l}\text { Percentage of Arg + } \\
\text { ve cases }\end{array}$ \\
\hline Normal & 317 & 158 & 49.842 \\
Dysplasia & 27 & 25 & 92.592 \\
\hline
\end{tabular}

No: Number; Arg: Argyrophilic cells.

tions which showed positivity with Grimelius argyrophilic reaction were selected. About 60 unstained sections of the same series from Normal uterine cervices and 12 unstained sections of the same series from Dysplastic uterine cervices were selected and used for immunohistochemistry method using Chromogranin A (Cg A) and Synaptophysin (SYN) as argyrophilic cell markers. Positive results aid in the classification of neuroendocrine tumours.

The percentage of argyrophilic positive cases in Normal was compared with Dysplastic human uterine cervices by using Chi-square test. The location of positivity and intensity of staining of $\mathrm{Cg}$ A and SYN for argyrophilic cells was observed in all the positive cases.

\section{Results}

In our study 317 normal uterine cervices were stained with Grimelius argyrophilic reaction to evaluate the presence of argyrophilic cells. Out of which 158 cases (49.84\%) were positive (Fig. 1A). About 27 dysplastic cases of uterine cervices were stained with Grimelius argyrophilic reaction out of which $25(92.59 \%)$ showed the argyrophilic positivity (Fig. 2A). The Argyrophil granules of the endocrine cells were impregnated yellow brown to black. When Normal cervix was compared with Dysplastic cervix the probability value $(\mathrm{P}$ value) was $<0.001$ which was significantly higher (Table 1 ).

For Immunohistochemical technique about 60 normal uterine cervices which showed argyrophilic cells were studied using $\mathrm{Cg}$ A and SYN as markers. $\mathrm{Cg}$ A positivity was shown in 28 cases $(46.6 \%)$ (Fig. 1B) and SYN positivity was observed in 26 cases (43.3\%) (Fig. 1C) (Table 2).

About 12 dysplastic uterine cervices which showed positivity with Grimelius reaction were selected for Immunohistochemical technique, out of which $5(41.6 \%)$ were positive for $\mathrm{Cg} \mathrm{A}$ (Fig. 2B) and $5(41.6 \%)$ were positive with SYN marker (Fig. 2C) (Table 2). The argyrophilic granules in the positive cells were immunostained into golden color.

\section{Discussion}

Carcinoids and adenocarcinomas with argyrophil cells are known to occur in the cervix and the ovary. They ectopically produce a variety of amines and peptide hormones. Argyrophil cells are suggested to be a counterpart of the neoplasm (APUDoma) derived from APUD (Amine Precursor Uptake and Decarboxylation) cells [20]. The major cause of CIN is chronic infection of the cervix with the sexually transmitted human papilloma virus (HPV). About a dozen of these types appear to cause cervical dysplasia and may lead to the development of cervical cancer. Dysplasia is a stepping stone to carcinoma [21].

The role of argyrophil cells and their relationship to CIN and invasive squamous carcinoma of the uterine cervix has not been studied extensively. Therefore this study was car-

Table 2. Comparison of Percentage of Chromogranin A and Synaptphysin Positive Cases in Normal With Dysplastic Conditions of Uterine Cervix

\begin{tabular}{|c|c|c|c|c|c|}
\hline Groups & No of Cases studied & $\begin{array}{l}\text { No. of } \mathrm{Cg} \mathrm{A+} \\
\text { ve Cases }\end{array}$ & $\begin{array}{l}\text { Percentage of } \mathrm{Cg} \mathrm{A}+ \\
\text { ve cases }\end{array}$ & $\begin{array}{l}\text { No. of SYN + } \\
\text { ve Cases }\end{array}$ & $\begin{array}{l}\text { Percentage of SYN + } \\
\text { ve cases }\end{array}$ \\
\hline Normal & 60 & 28 & 46.66 & 26 & 43.33 \\
\hline Dysplasia & 12 & 5 & 41.66 & 5 & 41.66 \\
\hline
\end{tabular}

No: Number; Cg A: Chromogranin A; SYN: Synaptphysin. 
ried out to elucidate a relationship of argyrophil cells in normal and dysplastic uterine cervices.

The presence of argyrophilic cells were demonstrated in 2 out of 120 normal cervices (1.66\%) by Fox et al [9] Tateishi et al [10] were also able to demonstrated argyrophilic cells in $35.18 \%$ of normal uterine cervical epithelium (19 out of 54 patients). Around 210 ectocervices were stained with Grimelius stain out of which only 11 ectocervices $(5.2 \%)$ showed positivity [22]. Argyrophil cells have been documented in the normal uterine cervix Fetissof et al [23] found two types of argyrophilic cells in $43 \%$ of ectocervices: serotonin cells and Merkel -type cells. Serotonin cells were essentially associated with "transitional-like" epithelium and Merkel-type cells with squamous epithelium.

The present study showed higher positivity $(92.59 \%)$ in dysplastic uterine cervix when compared with normal (49.84\%) uterine cervix. Hence, the percentage of positive cases was statistically significant in dysplastic condition of the uterine cervix when compared with normal cervix.

Both Cg A and SYN positivity was found in only $41.6 \%$ of Dysplastic cervix which is not significant when compared with $46.6 \%$ cases in normal uterine cervices.

Argyrophil cells in ectocervical epithelium are rare. Our study revealed that they are found in about $49.84 \%$ in normal and $92.59 \%$ in dysplastic uterine cervices, even though the immunohistochemical study has showed less positivity for Cg A and SYN in normal (46.6\%) well as in dysplastic (41.6\%) uterine cervices. Our study also revealed that only 2 cases of dysplastic uterine cervices were positive for both markers.

To our knowledge, it is the first study which reveals the comparison of the presence of argyrophilic cells in normal and dysplastic human uterine cervix, using Grimelius argyrophilic reaction and Immunohistochemical staining using $\mathrm{Cg} \mathrm{A}$ and SYN as argyrophilic markers with larger sample size and higher positivity.

\section{Conclusion}

From the results of our study it is clear that argyrophilia is a significant marker in dysplasia of the uterine cervix.

\section{Acknowledgement}

The authors are indebted to the faculty of Pathology Department, Kasturba Medical College Mangalore, for providing the hysterectomy specimens with histopathological diagnosis.

\section{Conflict of Interest}

None.

\section{Grant Support}

None.

\section{References}

1. Standring S, Ellis H, Healy JC, Johnson D, Williams A, et al. Gray's Anatomy, 39th ed. London, Elsevier Churchill Livingstone, 2005;1332-1335.

2. Kaminski P, Hoffman M, Payne K. Benign cervical Lesions. E Mediceine Web 2006; July (6).

3. Rosai and Ackerman's Surgical Pathology. 9th Edi. 2004, Juan Rosai Elsevier New York. Vol 1 pp 45-47 and Vol 2 pp 1523-1551.

4. Kumar, Vinay; Abbas, Abul K.; Fausto, Nelson; \& Mitchell, Richard N. (2007). Robbins Basic Pathology ((8th ed.), Saunders Elsevier. pp. 718-721.

5. Agorastos T, Miliaras D, Lambropoulos AF, Chrisafi S, Kotsis A, Manthos A, Bontis J. Detection and typing of human papillomavirus DNA in uterine cervices with coexistent grade I and grade III intraepithelial neoplasia: biologic progression or independent lesions? Eur J Obstet Gynecol Reprod Biol. 2005;121(1):99-103.

6. Rosai and Ackerman`s Surgical Pathology. 8th Edi. 1987, New York, Anne S Patterson, PP 2559, 27202721.

7. Sivridis E, Buckley CH, Fox H. Argyrophil cells in normal, hyperplastic, and neoplastic endometrium. J Clin Pathol. 1984;37(4):378-381.

8. Lee SJ, Rollason TP. Argyrophilic cells in cervical intraepithelial glandular neoplasia. Int J Gynecol Pathol. 1994;13(2):131-132.

9. Fox H, Kazzaz B, Langley FA. Argyrophil and Argentaffin Cells in the Female Genital Tract and in Ovarian Mucinous Cysts. J Pathol Bacteriol. 1964;88:479-488.

10. Tateishi R, Wada A, Hayakawa K, Hongo J, Ischii S. \& Terakawa N, Argyrophil cell carcinoma (apudomas) of the uterine cervix: light and electron microscopic observation of 5 cases. Virchows Archive. Pathological Anatomy, 1975; 366:257-274.

11. Mullins JD, Hilliard GD. Cervical carcinoid ("argyrophil cell" carcinoma) associated with an endocervical adenocarcinoma: a light and ultrastructural study. Cancer. 1981;47(4):785-790.

12. Bannatyne P, Russell P, Wills EJ. Argyrophilia and endometrial carcinoma. Int J Gynecol Pathol. 1983;2(3):235254.

13. Crum CP and Nuovo GJ. The Cervix, Diagnostic Surgical Pathology, 2nd Edi. 1994, New York, Raven Press Ltd, pp 2055-2086.

14. Grimelius L. A silver nitrate stain for alpha-2 cells in human pancreatic islets. Acta Soc Med Ups. 1968;73(56):243-270. 
15. WHO Histopathological typing of endocrine tumours No.23, 1980: 62.

16. Fernandez Pascual JS. A new method for easy demonstration of argyrophil cells. Stain Technol. 1976;51(4):231235.

17. Sheehan D, Hrapchak B, Theory and practice of Histotechnology 2nd Ed, 1980, pp 278-279, Battelle Press, Ohio.

18. Crookham J, Dapson R. Hazardous Chemicals in the Histopathology Laboratory, 2nd ED, 1991, Anatech.

19. Bancroft JD, Stevens A. Theory and Practice of Histological Techniques, 3rd Edi. 1990, New York, Churchill Livingstone. Pp 258-259, 285.

20. Inoue M, Ueda G, Nakajima T. Immunohistochemical demonstration of neuron-specific enolase in gynecologic malignant tumors. Cancer. 1985;55(8):1686-1690.

21. Kishi K, Hirota T, Kasamatsu T, Sonoda T, Matsumoto Y, Ohmi K, Tanemura K, Tsunematsu R, Yamada T. Dysplasia of the uterine cervix. Japanese Journal of Clinical Oncology. 1979; 9:255-260.

22. Fetissof F, Arbeille B, Boivin F, Sam-Giao M, Henrion C, Lansac J. Endocrine cells in ectocervical epithelium. An immunohistochemical and ultrastructural analysis. Virchows Arch A Pathol Anat Histopathol. 1987;411(3):293-298.

23. Fetissof F, Serres G, Arbeille B, de Muret A, Sam-Giao M, Lansac J. Argyrophilic cells and ectocervical epithelium. Int J Gynecol Pathol. 1991;10(2):177-190. 